\title{
ORIGINAL ARTICLEIARTIGO ORIGINAL
}

\section{Profile of deaths from unspecified stroke after investigation of garbage codes in 60 cities in Brazil, 2017}

\section{Perfil dos óbitos por acidente vascular cerebral não especificado após investigação de códigos garbage em 60 cidades do Brasil, 2017}

\author{
Samira Nascimento Mamed' (D), Ana Maria de Oliveira Ramos" (1), \\ Valdelaine Etelvina Miranda de Araújo'II (D), Wagner Santos de Jesus IV (D), \\ Lenice Harumi Ishitaniv (D), Elisabeth Barboza França ${ }^{\mathrm{VI}}$ (1)
}

\begin{abstract}
Introduction: Unspecified stroke (UnST) is of great importance in mortality statistics, as it is the fourth leading cause of death in Brazil. The objective of this study was to identify the profile of reclassified causes of death after investigation of deaths caused by UnST in Brazil. Methods: All deaths registered as UnST in 2017 in the Mortality Information System (SIM) were considered as garbage codes. The specific causes, detected after investigation in 60 selected cities, were analyzed by age and sex. Results: Of the total deaths due to UnST identified in these 60 cities $(n=11,289), 25.8 \%$ were investigated. Of these, $56.3 \%$ were reclassified to ischemic stroke, $12.7 \%$ to hemorrhagic stroke, and $23.3 \%$ to other specific causes, such as diabetes and chronic kidney disease, in both sexes. Discussion: The higher proportion of deaths due to ischemic stroke in comparison to hemorrhagic stroke was expected. However, the detection of other specific causes outside the stroke group indicates possible quality problems in the filling of death certificate (DC). Conclusion: The investigations allowed the identification of subgroups of deaths due to stroke. In addition to the research, however, it is important to conduct physician training in the adequate filling in of the DC, in order to improve estimates of specific stroke mortality, and to enable appropriate targeting of health actions and services.
\end{abstract}

Keywords: Death certificates. Cause of death. Stroke. Health information systems.

'Epidemiological Surveillance Board, Municipal Department of Health - Goiânia (GO), Brazil.

"Death Verification Service, State Department of Public Health of Rio Grande do Norte - Natal (RN), Brazil.

"'Health Surveillance Department, Ministry of Health - Brasília (DF), Brazil.

vHealth Surveillance Board, State Department of Health of Tocantins - Palmas (TO), Brazil.

VEpidemiology and Health Assessment Research Group, Universidade Federal de Minas Gerais - Belo Horizonte (MG), Brazil.

"'Graduate Program on Public Health, School of Medicine, Universidade Federal de Minas Gerais - Belo Horizonte (MG), Brazil.

Corresponding author: Samira Nascimento Mamed. Palácio das Campinas (Paço Municipal). Avenida do Cerrado, 999, bloco D,

$11^{\circ}$ andar, room 4, Park Lozandes, CEP: 74884-900, Goiânia, GO, Brasil. Email: samiramamed31@gmail.com

Conflict of interest: nothing to declare - Financial support: Vital Strategies, as part of the Data for Health Initiative of the Bloomberg Philanthropies Foundation (Project 23998 Fundep/UFMG). 
RESUMO: Introdução: O acidente vascular cerebral não especificado (AVC-NE) é de grande relevância nas estatísticas de mortalidade, sendo a quarta maior causa de morte no Brasil. O objetivo deste estudo foi identificar o perfil de causas reclassificadas após investigação de óbitos por AVC-NE no Brasil. Métodos: Foram selecionados todos os óbitos registrados em 2017 no Sistema de Informação sobre Mortalidade (SIM) como AVC-NE, considerados códigos garbage. As causas específicas, detectadas após investigação em 60 cidades selecionadas, foram analisadas segundo idade e sexo. Resultados: Do total de óbitos por AVC-NE das 60 cidades ( $\mathrm{n}=11.289$ ), foram investigados $25,8 \%$, dos quais $56,3 \%$ foram reclassificados para AVC isquêmico, $12,7 \%$ para AVC hemorrágico, e 23,3\% migraram para outras causas específicas, como diabetes e doença renal crônica, em ambos os sexos. Discussão: A maior proporção de reclassificação dos óbitos por AVC-NE para AVC isquêmico em relação ao hemorrágico era esperada. No entanto, a detecção de outras causas específicas fora do grupo de AVC indica possíveis problemas de qualidade do preenchimento das causas na declaração de óbito (DO). Conclusão: As investigações realizadas permitiram identificação de subgrupos de AVC. Além da investigação, entretanto, é importante realizar capacitação com médicos para o preenchimento adequado da DO, a fim de melhorar as estimativas da mortalidade por AVC específico e possibilitar direcionamento adequado das ações e dos serviços de saúde.

Palavras-chave: Atestado de óbito. Causas de morte. Acidente vascular cerebral. Sistemas de informação em saúde.

\section{INTRODUCTION}

Stroke is defined as a sudden neurological deficit resulting from a vascular lesion. This lesion has an acute, variable-duration installation and can lead to death. Its severity varies according to the site and intensity with which the vascular lesion occurs ${ }^{1}$. There are three major subgroups of stroke, classified as follows: ischemic stroke, intracerebral hemorrhage, and subarachnoid hemorrhage ${ }^{2}$. Ischemic stroke subtypes are classified as lacunar, atherosclerotic, and embolic ${ }^{3,4}$.

Between 2003 and 2013, stroke ceased to occupy an anonymous position, covered by the term "cardiovascular disease", and became recognized as an autonomous non-transmissible disease, with great implications for global health ${ }^{5}$. There is still no country in the world where the stroke burden, in terms of the absolute number of people affected or who died from stroke, has declined in the last two decades ${ }^{6}$.

Stroke is a disease influenced by several factors, with more than 150 known causes 7 . Diabetes constitutes a risk factor for stroke through direct atherogenic mechanisms and by interacting with other risk factors, such as hypertension and hyperlipidemia ${ }^{8}$. Cerebral atherosclerosis is the main cause of ischemic stroke. In the 1930s, a study of autopsies indicated that more than $70 \%$ of ischemic stroke cases were due to atherosclerosis, and only $3 \%$ to embolism $\%$. Hypertension is the main risk factor for hemorrhagic stroke, consequent to rupture of a vessel in the intimacy of the cerebral parenchyma. Other causes of hemorrhagic stroke are coagulation alterations, subarachnoid hemorrhages due to the existence of arteriovenous malformations or aneurysm ruptures, among others ${ }^{10,11}$. 
Although it has been demonstrated the importance of recognizing stroke as a vascular disease to be faced in particular and of great importance in vital statistics ${ }^{12}$, unspecified stroke (UnST) still has great relevance in statistics in Brazil, being the fourth cause of death recorded in the Mortality Information System (Sistema de Informação sobre Mortalidade SIM) in 2015, surpassed only by ischemic heart disease, pneumonia and ill-defined causes ${ }^{13}$.

A difficulty found in mortality statistics for knowing the real magnitude of the types of stroke is the certification of UnST, cause included in the list of garbage codes (GC). The garbage causes of death are considered inadequate or of no use for public health purposes ${ }^{14-17}$.

In the Global Burden of Disease study (GBD) the codes of the International Statistical Classification of Diseases and Health-Related Problems, $10^{\text {th }}$ Revision (ICD-10) for UnST are redistributed by statistical methods to ischemic and hemorrhagic subgroups ${ }^{14}$, but the fractions of redistribution are not presented. There are few studies that present the UnST fractions used for redistribution to the hemorrhagic, ischemic, and subarachnoid stroke subtypes $^{18}$. On the other hand, empirical methods may represent new and more accurate strategies in evaluating the actual occurrence of deaths by these subgroups. Thus, this study aimed to identify the fractions of specific causes detected after investigation of deaths from UnST in adults.

\section{METHODS}

This is a cross-sectional study on the profile and reclassification of deaths of people aged 30 years or over, whose underlying causes recorded in the death certificate (DC) were classified as UnST in Brazil in 2017. The study is part of the project "Improvement of the diagnosis of cause of death in Brazil", conducted in partnership between the Ministry of Health and the Universidade Federal de Minas Gerais (UFMG), with the external partnership of Vital Strategies and the University of Melbourne by the Bloomberg Foundation. The project was implemented in 60 cities of the five regions of Brazil that adhered to the study voluntarily, tacking into consideration the structure of their epidemiological surveillance teams. In this study, the term city was used as a synonym for the municipality and covers all its territorial extension, including deaths occurred in urban and rural areas.

More than $85 \%$ of deaths from UnST to be investigated in the 60 cities occurred in those with more than 500,000 inhabitants, possibly with greater access to healthcare services, quality of care, and qualified health professionals involved in the process. In fact, in the analysis of deaths according to the population size of cities ( $>500,000$ inhabitants; from 100,001 to 500,000 ; and 100,000 or less), according to the medical assistance variable and also according to R98 and R99 codes, it was observed that the strata of larger cities had lower proportions of deaths without care and also with R98 or R99 codes. These data indicate that these cities would tend to have more structured health facilities with higher capacity for investigation.

The following ICD-10 ${ }^{19}$ codes were considered as UnST, according to the 2015 GBD study list: I64, I67.4, I67.9, I69.4, I69.8 ${ }^{14}$. The I67.8 code was excluded from the GC list, considering 
that in Brazil this code is used for ischemic stroke ${ }^{20}$. For this reason, for the reclassification of deaths, the I67.8 code was added to specific causes.

The data referring to deaths of residents of the 60 cities occurring in 2017 were obtained from the SIM, which is fed from information contained in the DC. Deaths were selected according to the following criteria: residence of the deceased person in some of the 60 cities under study, age $\geq 30$ years, and original underlying cause encoded as UnST. Based on these eligible deaths ( $\mathrm{n}=11,289$ ) we initially estimated the frequencies (absolute and relative) of the main sociodemographic characteristics (sex, age group, race, educational level, region of residence) and other selected variables, such as the place of death, certifier physician, and whether the death was investigated or not.

The investigations were conducted by the epidemiological surveillance teams of the municipal health departments. Initially, the DCs were reviewed to correct possible inadequacies in the typing or coding of the underlying cause. The teams selected hospital deaths of residents of the city and searched for information in hospital records and, when necessary for supplementation, in health services such as the Death Verification Service (SVO) and the Forensic Medical Institute (IML). After, the teams changed the cause of death in the SIM. This process of investigation and registration in the SIM followed the guidelines contained in the "Protocol for investigating deaths with causes classified as garbage codes - 60 cities in Brazil"21 . It should be noted that the hospital investigations were not proposed for all deaths from UnST, as recommended in the protocol, which established the strategy of prioritizing the conduct of investigations in hospitals with a higher volume of garbage causes. Some cities prioritized hospitals with a positive history of collaboration with surveillance services.

For all deaths investigated in hospitals, an investigation form containing variables was filled in enabling reclassification of the underlying cause originally defined as GC. The variables used in hospital investigation include: date of hospitalization, circumstance of referral to hospitalization, information on pre-hospital care, findings and clinical evolution, more relevant exams to reclassify the cause of death, procedures performed during hospitalization, and information about comorbidities that may have contributed to death. The data collected in the hospital investigation of each death were submitted to review and certification by physicians who reclassified or not the original underlying cause of death. In general, the physicians were part of the epidemiological surveillance team of the municipal health department and had experience in the certification of causes of death.

The new underlying causes of death after investigation were categorized according to the level of certainty of the diagnosis, according to criteria adapted from Serina et al. ${ }^{22}$, namely: (1) definitive: diagnosis with the highest level of certainty for certain health condition, confirmed through laboratory examination or imaging, and/or clinical history documented by specific signs and symptoms in those clinical conditions in which there are no supplementary evidentiary exams; (2) probable: diagnosis with a high level of certainty for a given health condition through the documented clinical history by specific signs and symptoms, in the absence of specific supplementary exams; (3) possible: diagnosis that does not reach the previous criteria for a given health condition. 
The new underlying causes were included in the municipal SIM and in an online database called Collect, created by the Brazilian Ministry of Health to include the causes investigated in hospitals. This database allows the evaluation of criteria used in the reclassification of causes of death, specifying the level of certainty of the diagnosis of the cause defined after investigation. Thus, in this study, the selection of deaths from UnST was based on two complementary information systems, SIM and Collect. In the SIM, among the eligible deaths of the 60 cities $(n=11,289)$, we selected those that had the variable investigation filled in with a "yes" ( $\mathrm{n}=2,910)$ and in which the underlying cause had changed after investigation $(n=2,116)$. For comparison, we selected the SIM deaths that had the data from investigations inserted into Collect, and which had the level of certainty of diagnosis of the underlying cause in this system identified as "definitive" or "probable" $(n=616)$, as shown in Figure 1.

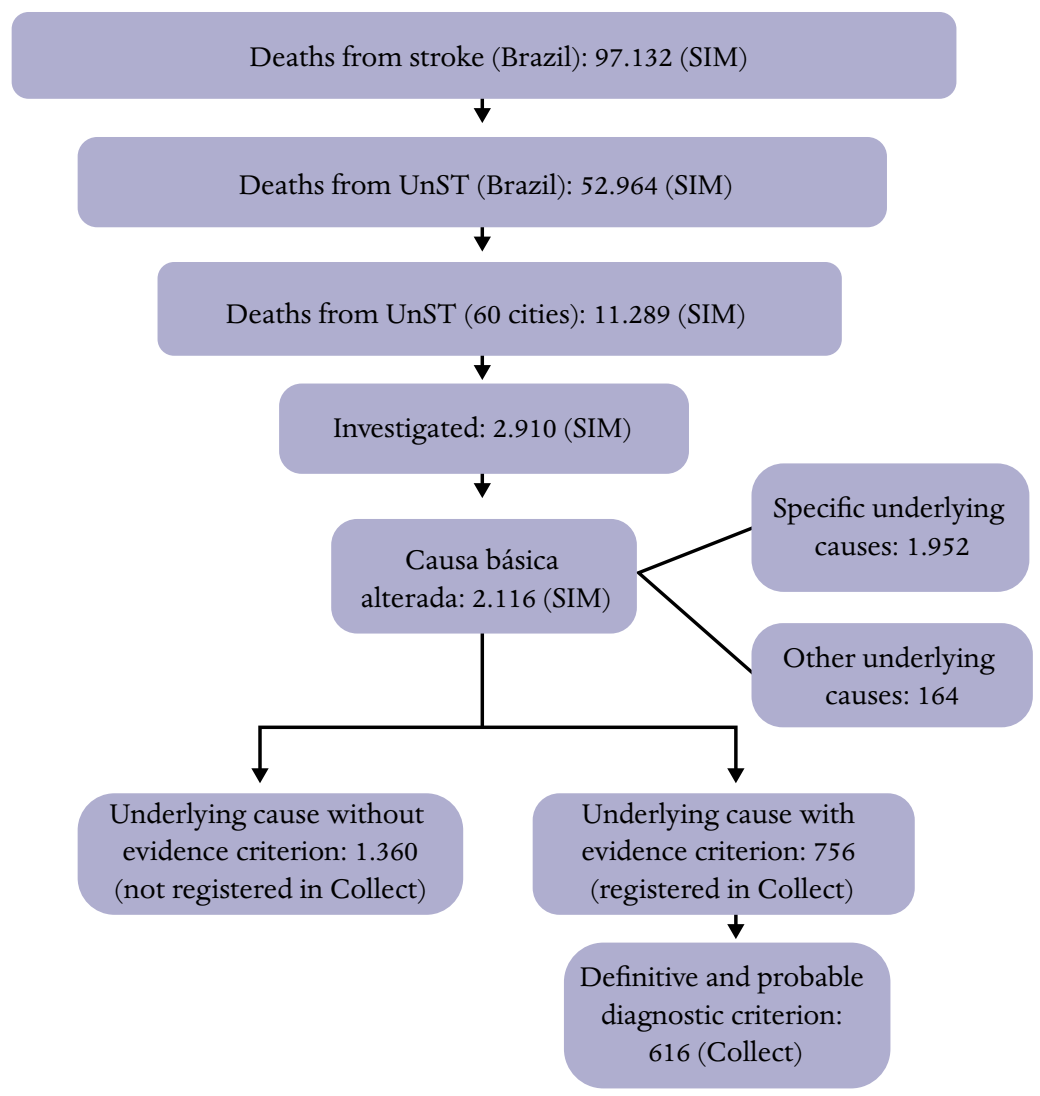

Figure 1. Selection of Deaths by Unspecified Stroke in 60 cities, Brazil, 2017.

Source: Data from the Mortality Information System (SIM) (2017), updated on April 8, 2019, and from the investigations entered into Collect (2017).

We calculated the absolute and relative frequencies of the deaths investigated and reclassified to a specific cause per federation unit (FU). The underlying causes of death after investigation, 
registered in SIM ( $\mathrm{n}=2,116)$ and Collect with a level of certainty of diagnosis as "definitive" or "probable" ( $n=616$ ), were grouped according to the 2015 GBD study list of causes, and calculated proportions according to sex and age groups (from 30 to 69 years; 70 years and over). To check the difference in proportions between information in SIM and Collect, the chi-square test was used.

This study was approved by the Research Ethics Committee of UFMG (CAEE 7555317.0.0000.51 49) and developed according to the ethical precepts established in Ordinance No. 466/2012 of the National Health Council.

\section{RESULTS}

Of the total deaths from UnST of the 60 cities ( $n=11,289), 25.8 \%(n=2,910)$ were investigated, $53.3 \%$ of which were female. Overall, investigated and non-investigated deaths presented relatively similar frequency distributions for the variables sex, age group, race, educational level and certifier physician (Table 1).

Of the investigated deaths, $69.8 \%$ occurred in the age group of 70 years and over, and $30.2 \%$ in the age group from 30 to 69 years. Whites and blacks (black and brown) had $47.9 \%$ and $46.8 \%$ of the deaths from UnST investigated, respectively. Almost half $(48.2 \%)$ of the investigated deaths were uneducated people or with an education of up to three years (data not presented). Concerning the region of residence, $6.9 \%$ and $3.6 \%$ of the total deaths from UnST were of residents of the South and Midwest regions, which contributed with $17.8 \%$ and $6.4 \%$ of the investigated deaths, respectively. The opposite was observed in the Southeast region, which, despite contributing to almost half of the total number of deaths $(46.6 \%)$, had only one third (34.9\%) investigated. Regarding the place of occurrence, $84.9 \%$ of the investigated deaths occurred in hospitals, and $8.2 \%$ at home. Most of the investigated deaths were certified by substitute physicians (38.9\%), followed by other physicians $(29.2 \%)$, and assistant physicians (24.5\%) (Table 1$)$.

Table 1. Socio-demographic characteristics and occurrence of deaths with underlying cause of death classified as Unspecified Stroke, according to the investigation, 60 cities, Brazil, 2017.

\begin{tabular}{l|c|c|c|c|c|c|c|}
\multirow{2}{*}{$\begin{array}{c}\text { Characteristics } \\
\mathrm{n}=2,910\end{array}$} & \multicolumn{2}{|c|}{ Investigated } & \multicolumn{2}{c|}{ Not investigated } & \multicolumn{2}{c}{ TOTAL } \\
\cline { 2 - 7 } & $\mathrm{n}=2,910$ & $\%$ & $\mathrm{n}=8,379$ & $\%$ & $\mathrm{n}=11,289$ & $\%$ \\
\hline Sex & 1,550 & 53.3 & 4,342 & 51.8 & 5,892 & 52.2 \\
\hline Female & 1,360 & 46.7 & 4,037 & 48.2 & 5,397 & 47.8 \\
\hline Male & 879 & 30.2 & 2,277 & 27.2 & 3,156 & 28.0 \\
\hline Age range & 2,031 & 69.8 & 6,102 & 72.8 & 8,133 & 72.0 \\
\hline 30 to 69 years & & & & & \\
\hline 70 years and more & & & & & & \\
\hline
\end{tabular}


Table 1. Continuation.

\begin{tabular}{|c|c|c|c|c|c|c|}
\hline \multirow{2}{*}{$\begin{array}{l}\text { Characteristics } \\
\qquad n=2,910\end{array}$} & \multicolumn{2}{|c|}{ Investigated } & \multicolumn{2}{|c|}{ Not investigated } & \multicolumn{2}{|c|}{ TOTAL } \\
\hline & $n=2,910$ & $\%$ & $n=8,379$ & $\%$ & $n=11,289$ & $\%$ \\
\hline \multicolumn{7}{|l|}{ Race/color } \\
\hline White & 1,394 & 47.9 & 3,834 & 45.8 & 5,228 & 46.3 \\
\hline Brown & 1,136 & 39.0 & 3,397 & 40.5 & 4,533 & 40.2 \\
\hline Black & 228 & 7.8 & 853 & 10.2 & 1,081 & 9.6 \\
\hline Yellow & 18 & 0.6 & 68 & 0.8 & 86 & 0.8 \\
\hline Indigenous & 4 & 0.1 & 9 & 0.1 & 13 & 0.1 \\
\hline \multicolumn{7}{|l|}{ Region of residence } \\
\hline Southeast & 1,016 & 34.9 & 4,240 & 50.6 & 5,256 & 46.6 \\
\hline Northeast & 855 & 29.4 & 2,683 & 32.0 & 3,538 & 31.3 \\
\hline North & 335 & 11.5 & 964 & 11.5 & 1,299 & 11.5 \\
\hline South & 519 & 17.8 & 265 & 3.2 & 784 & 6.9 \\
\hline Midwest & 185 & 6.4 & 227 & 2.7 & 412 & 3.6 \\
\hline \multicolumn{7}{|l|}{ Place of occurrence } \\
\hline Hospital & 2,471 & 84.9 & 6,009 & 71.7 & 8,480 & 75.1 \\
\hline Home & 238 & 8.2 & 1,432 & 17.1 & 1,670 & 14.8 \\
\hline Others & 201 & 6.9 & 938 & 11.2 & 1,139 & 10.1 \\
\hline \multicolumn{7}{|l|}{ Certifier physician } \\
\hline Substitute & 1,131 & 38.9 & 2,657 & 31.7 & 3,788 & 33.6 \\
\hline Others & 851 & 29.2 & 2,963 & 35.4 & 3,814 & 33.8 \\
\hline Assistant & 714 & 24.5 & 2,070 & 24.7 & 2,784 & 24.7 \\
\hline Death Verification Service & 170 & 5.8 & 646 & 7.7 & 816 & 7.2 \\
\hline
\end{tabular}

Note: not including cases without information (348 in race/color and 1,771 in educational level).

Source: Data from the Mortality Information System (SIM) (2017), updated on April 8, 2019.

Of 2,910 deaths from UnST investigated in the SIM (25.8\%), it was observed that three states investigated more than $70 \%$ of deaths: Acre (100\%), Santa Catarina $(77.2 \%)$, and Tocantins (71.3\%). Sergipe, Mato Grosso, Roraima, Paraná and Alagoas investigated between $40 \%$ and $70 \%$ of the deaths (Table 2 ).

Regarding reclassification, $67.1 \%(n=1,952)$ of the deaths from UnST had the underlying cause changed to specific causes after investigation. Most of the states reclassified more than half of the investigated deaths, highlighting Acre, where $100 \%$ of the deaths due to UnST were investigated and all were reclassified. However, it should be noted that this state 
had the lowest total number of deaths from UnST. Other states with higher frequencies of deaths from UnST had a lower percentage of cases investigated, such as Amazonas (5.5\%), Bahia $(8.1 \%)$, and Rio de Janeiro $(8.9 \%)$, but showing a much higher proportion of reclassification to specific causes: $64.7 \%, 47.9 \%$, and $45.5 \%$, respectively (Table 2 ).

Table 2. Investigated deaths from unspecified stroke reclassified to specific underlying cause, by region and states of 60 cities, Brazil, 2017.

\begin{tabular}{|c|c|c|c|c|c|c|}
\hline \multirow[t]{2}{*}{ Region } & \multirow[t]{2}{*}{ Federation unit } & \multirow{2}{*}{$\begin{array}{c}\text { UnST } \\
\mathbf{n}\end{array}$} & \multicolumn{2}{|c|}{ Investigated } & \multicolumn{2}{|c|}{$\begin{array}{l}\text { Investigated and } \\
\text { changed to specific } \\
\text { underlying cause }\end{array}$} \\
\hline & & & $\mathbf{n}$ & $\%$ & $\mathbf{n}$ & $\%$ \\
\hline \multirow{7}{*}{ NORTH } & Acre & 11 & 11 & 100.0 & 11 & 100.0 \\
\hline & Amapá & 100 & 4 & 4.0 & 1 & 25.0 \\
\hline & Amazonas & 309 & 17 & 5.5 & 11 & 64.7 \\
\hline & Pará & 659 & 178 & 27.0 & 121 & 68.0 \\
\hline & Rondônia & 64 & 20 & 31.3 & 18 & 90.0 \\
\hline & Roraima & 48 & 28 & 58.3 & 26 & 92.9 \\
\hline & Tocantins & 108 & 77 & 71.3 & 65 & 84.4 \\
\hline \multirow{7}{*}{ NORTHEAST } & Alagoas & 491 & 222 & 45.2 & 104 & 46.8 \\
\hline & Bahia & 881 & 71 & 8.1 & 34 & 47.9 \\
\hline & Ceará & 1,001 & 206 & 20.6 & 75 & 36.4 \\
\hline & Paraíba & 177 & 34 & 19.2 & 19 & 55.9 \\
\hline & Pernambuco & 671 & 154 & 23.0 & 64 & 41.6 \\
\hline & Rio Grande do Norte & 143 & 48 & 33.6 & 46 & 95.8 \\
\hline & Sergipe & 174 & 120 & 69.0 & 61 & 50.8 \\
\hline \multirow{3}{*}{ SOUTHEAST } & Minas Gerais & 532 & 193 & 36.3 & 145 & 75.1 \\
\hline & Rio de Janeiro & 2,398 & 213 & 8.9 & 97 & 45.5 \\
\hline & São Paulo & 2,326 & 610 & 26.2 & 535 & 87.7 \\
\hline \multirow{2}{*}{ SOUTH } & Paraná & 442 & 255 & 57.7 & 130 & 51.0 \\
\hline & Santa Catarina & 342 & 264 & 77.2 & 225 & 85.2 \\
\hline \multirow{3}{*}{ MIDWEST } & Goiás & 234 & 73 & 31.2 & 61 & 83.6 \\
\hline & Mato Grosso & 178 & 112 & 62.9 & 103 & 92.0 \\
\hline & Total & 11,289 & 2,910 & 25.8 & 1,952 & 67.1 \\
\hline
\end{tabular}

UnST: unspecified stroke.

Source: Data from the Mortality Information System (SIM) (2017), updated on April 8, 2019. 
We have observed similarities in the percentage distribution by sex and age group of deaths from UnST investigated and which changed the underlying cause registered in the SIM and Collect $(\mathrm{p}>0.05)$. The percentage of reclassification increased with age in both sexes, with the highest percentages being found in those older than 80 years. In this age group, approximately half of the female deaths were reclassified $(51.7 \%$ in the SIM and $47.6 \%$ in Collect), whose values were higher than those of males (33.6\% in SIM and $33.9 \%$ in Collect) (Chart 1).

Regarding the reclassification of underlying cause of death after investigation, it was found that, of the UnST, 49.1\% (male) and 56.0\% (female) were reclassified to ischemic stroke, and $14.0 \%$ and $11.5 \%$ to hemorrhagic stroke in men and women, respectively. For both sexes, these percentages were $56.3 \%$ for ischemic stroke and $12.7 \%$ for hemorrhagic stroke. The reclassification of deaths from UnST to ischemic stroke was more frequent in the age group of 70 years and over. However, the reclassification to hemorrhagic stroke was more frequent in the age group of 30 to 69 years. In these two situations, there was little difference between the sexes (Table 3 ).

Among the deaths from UnST in both sexes, 7.7\% remained as GC even after investigation, being $5.4 \%$ as UnST and $2.3 \%$ as other GC not associated with UnST (Table 3). In addition, $23.3 \%$ in both sexes migrated to other specific causes that do not belong to the stroke group, such as diabetes (5.4\%), atrial flutter $(2.2 \%)$, chronic kidney disease (2.0\%), Alzheimer's and other dementia (1.7\%), ischemic heart disease $1.7 \%)$, and falls, with $1.5 \%$ (data not presented).

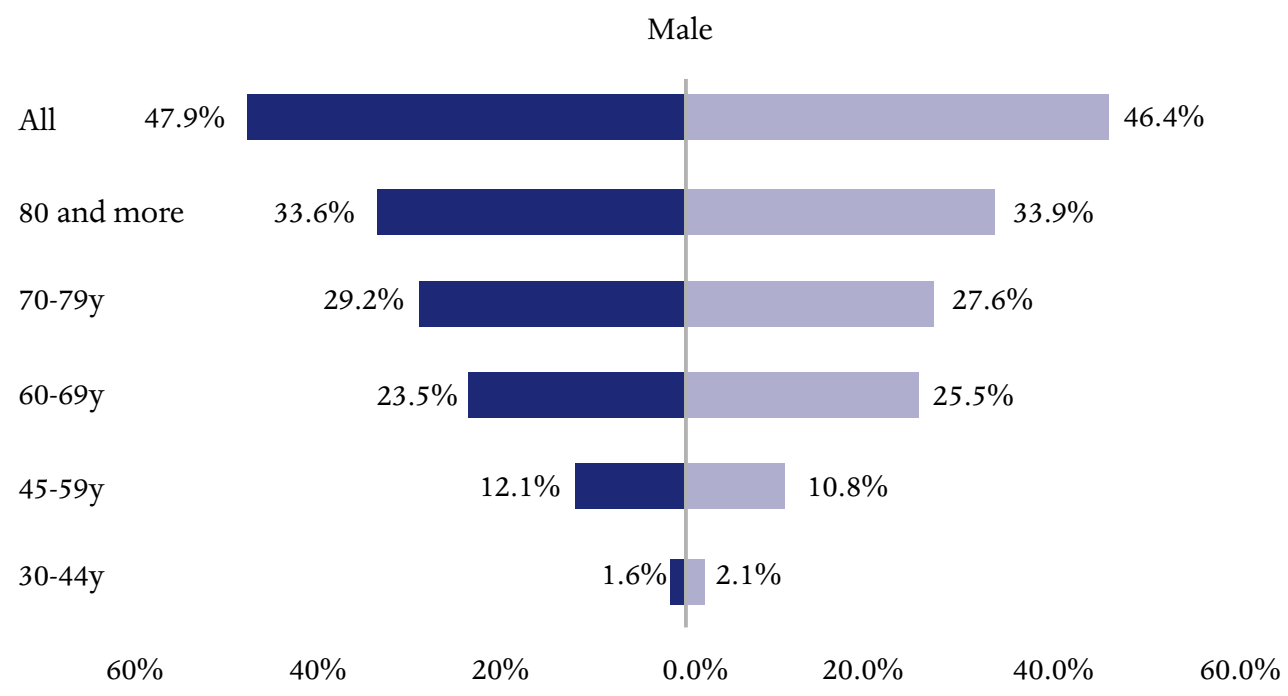

UnST SIM Cases

UsST Colect Cases 


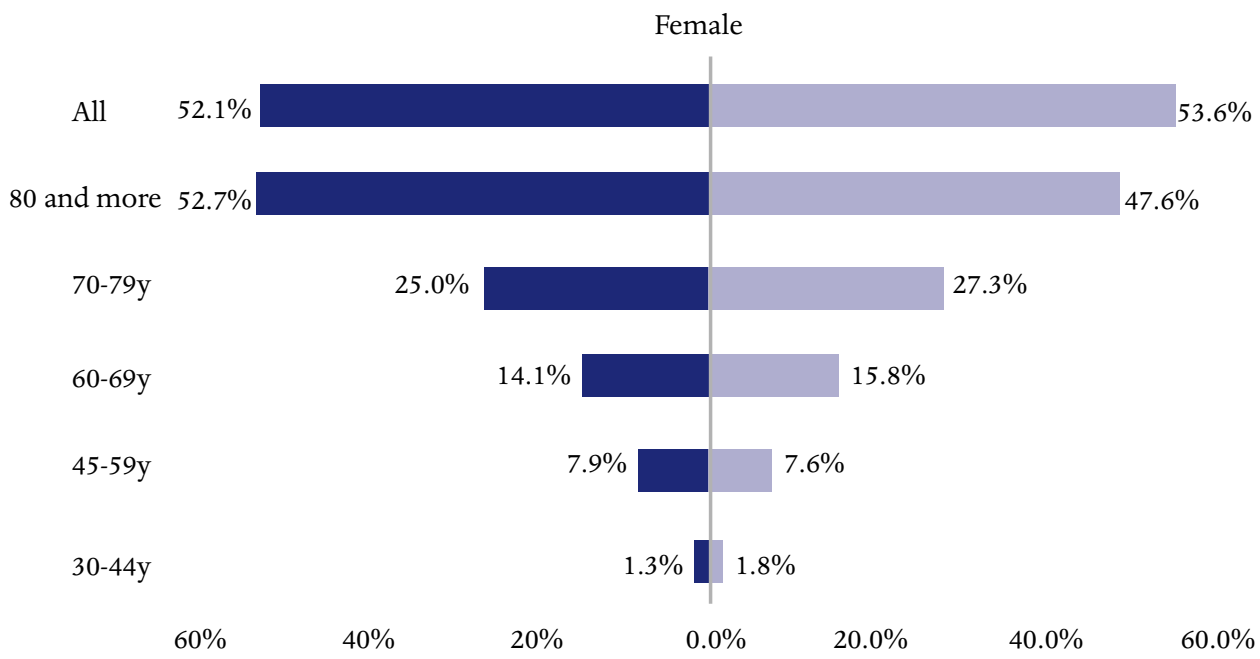

UnST SIM Cases

UsST Colect Cases

Chart 1. Percentage of deaths from Unspecified Stroke with the underlying cause changed in the Mortality Information System (SIM) and Collect, according to sex and age range, 60 cities, Brazil, 2017.

y: years; UnST: unspecified stroke.; SIM: Mortality Information System. Note: 1,014 male deaths and 1,102 female deaths with underlying cause changed (investigations in SIM from various sources), and 616 from hospital

investigations included in Collect with definitive or probable level of diagnosis (male: $n=286$; and female: $n=330$ ).

Non-significant chi-square test for each sex separately $(p>0.05)$.

Source: Data from Sistema de Informação sobre Mortalidade (SIM) (2017), updated on April 8, 2019, and investigations entered into Collect (2017).

Table 3. Reclassification of the underlying cause of death from unspecified stroke after investigation, according to sex and age group, in the SIM and Collect* databases, 60 cities, Brazil, 2017.

\begin{tabular}{|c|c|c|c|c|c|c|c|c|c|c|c|c|}
\hline \multirow{3}{*}{$\begin{array}{l}\text { Reclassified } \\
\text { cause* * }^{*}\end{array}$} & \multicolumn{4}{|c|}{30 to 69 years } & \multicolumn{4}{|c|}{70 years and more } & \multicolumn{4}{|c|}{ Total } \\
\hline & \multicolumn{2}{|c|}{ Collect* } & \multicolumn{2}{|c|}{ SIM } & \multicolumn{2}{|c|}{ Collect* } & \multicolumn{2}{|c|}{ SIM } & \multicolumn{2}{|c|}{ Collect* } & \multicolumn{2}{|c|}{ SIM } \\
\hline & $\mathrm{n}$ & $\%$ & $\mathrm{n}$ & $\%$ & $\mathrm{n}$ & $\%$ & $\mathrm{n}$ & $\%$ & $n$ & $\%$ & $\mathrm{n}$ & $\%$ \\
\hline \multicolumn{13}{|l|}{ Male } \\
\hline I-Stroke*** & 51 & 46.4 & 210 & 55.7 & 103 & 58.5 & 364 & 57.1 & 154 & 53.8 & 574 & 49.1 \\
\hline H-Stroke & 23 & 20.9 & 73 & 19.4 & 17 & 9.7 & 69 & 10.8 & 40 & 14.0 & 142 & 14.0 \\
\hline Specified\& & 35 & 31.8 & 72 & 19.1 & 50 & 28.4 & 153 & 24.0 & 85 & 29.7 & 225 & 22.2 \\
\hline UnST & 1 & 0.9 & 17 & 4.5 & 4 & 2.3 & 38 & 6.0 & 5 & 1.7 & 55 & 5.4 \\
\hline Other GC\# & 0 & 0.0 & 5 & 1.3 & 2 & 1.1 & 13 & 2.0 & 2 & 0.7 & 18 & 9.3 \\
\hline Total & 110 & 100 & 377 & 100 & 176 & 100 & 637 & 100 & 286 & 100 & 1014 & 100 \\
\hline
\end{tabular}


Table 3. Continuation.

\begin{tabular}{|c|c|c|c|c|c|c|c|c|c|}
\hline \multirow{3}{*}{$\begin{array}{l}\text { Reclassified } \\
\text { cause* * }\end{array}$} & \multicolumn{4}{|c|}{30 to 69 years } & \multicolumn{4}{|c|}{70 years and more } & Total \\
\hline & & & & & & & & & \\
\hline & $\mathrm{n}$ & $\%$ & $\mathrm{n}$ & $\%$ & $\mathrm{n}$ & $\%$ & $\mathrm{n}$ & & $\%$ \\
\hline
\end{tabular}

Female

\begin{tabular}{|l|c|c|c|c|c|c|c|c|c|c|c|c|}
\hline I-Stroke*** & 32 & 38.6 & 126 & 49.2 & 137 & 55.5 & 491 & 58.0 & 169 & 51.2 & 617 & 56.0 \\
\hline H-Stroke & 17 & 20.5 & 47 & 18.4 & 24 & 9.7 & 80 & 9.5 & 41 & 12.4 & 127 & 11.5 \\
\hline Specified\& & 32 & 38.6 & 69 & 27.0 & 70 & 28.3 & 198 & 23.4 & 102 & 30.9 & 267 & 24.2 \\
\hline UnST & 1 & 1.2 & 11 & 4.3 & 6 & 2.4 & 49 & 5.8 & 7 & 2.1 & 60 & 5.4 \\
\hline Other GC\# & 1 & 1.2 & 3 & 1.2 & 10 & 4.0 & 28 & 3.3 & 11 & 3.3 & 31 & 2.8 \\
\hline Total & 83 & 100 & 256 & 100 & 247 & 100 & 846 & 100 & 330 & 100 & 1102 & 100 \\
\hline
\end{tabular}

H-Stroke: hemorrhagic stroke; I-Stroke: ischemic stroke; UnST: unspecified stroke; SIM: Mortality Information System; * Level of certainty of diagnosis of underlying cause as "definitive" or "probable"; ** According to the grouping of cause of death of the 2015 Global Burden of Disease study; ${ }^{* \star}$ The 167.8 code was incorporated into this grouping; ${ }^{\star}$ Other specific causes, except specific stroke; " Other garbage causes, except UnST.

\section{DISCUSSION}

Through the investigations of deaths from UnST in 60 cities, it was found that $67 \%$ were reclassified to specific underlying causes in the SIM and there was a higher proportion of reclassification for ischemic stroke (49\% in males and $56 \%$ in females), being much lower for hemorrhagic stroke (14\% and $12 \%$ for men and women, respectively). In global estimates for 2016, the risk of occurrence of first ischemic stroke among people aged from 25 years is about 2.2 times higher than the risk of first hemorrhagic stroke ${ }^{23}$. In Brazil, an increase has also been observed in the incidence of ischemic stroke in young adults ${ }^{24}$. Ours is the first study of reclassification of deaths from UnST, therefore no results of Brazilian studies were found for comparison. Worldwide indirect estimates based on the GBD 2013 study, however, confirm higher proportions of redistribution of UnST to ischemic stroke (64.7\%) and lower for hemorrhagic stroke (30.8\%), with variable fractions according to age groups and regions of the world ${ }^{18}$.

High proportions of UnST as underlying causes of death reduce the quality of information about the causes of death and hinder the planning and adequate definition of health actions and assistance. Therefore, some studies have demanded efforts to correct ill-defined causes and GC, using indirect methods ${ }^{14}$. Correcting these causes of death with field-research, using data from medical records of hospitals and other health facilities, represents a possible alternative, as found in this study and in others conducted in the country ${ }^{25,26}$.

Deaths that had the underlying cause changed in the $\operatorname{SIM}(n=2,116)$ were equivalent to $72.7 \%$ of the number of investigated deaths in the SIM. This value was higher than that found in a study 
on investigation of ill-defined causes in Brazil in 2010, when $65.5 \%$ of deaths were reclassified ${ }^{26}$. With regard to the $27.3 \%(n=794)$ that did not have the underlying cause changed in this study, this was probably due to the difficulties in obtaining the necessary information for reclassification, difficulties in accessing the healthcare network, and the low quality of provided care and medical records in some establishments ${ }^{27,28}$. It is noted that some states had a low percentage of investigation, however they had a higher percentage of reclassification of underlying causes. This result is possibly related to the selection in this study of cities with a large population, in which the number of deaths is high, which hinders the investigation of all cases. In this situation, it is essential to structure surveillance teams to recover data that qualifies causeof-death information.

An unexpected result in this study was the reclassification of deaths from UnST to causes of death that are different from specific types of stroke, such as diabetes, atrial flutter, chronic kidney disease, Alzheimer's, ischemic heart disease and falls. These results indicate difficulties found in the quality of DC completion, in coding and selection of underlying causes of death, in investigation of death, in recertification of underlying cause of death, as well as in supply of technologies capable of providing physicians with the possibility of better diagnosis.

Regarding the two databases evaluated, it was observed that the deaths inserted in Collect are similar to the total number of investigated deaths inserted in the SIM relative to sex and age groups. On the other hand, a higher percentage of other specific causes that are different from stroke in the Collect system relative to the SIM can be noted. This result may be explained by the fact that, in the first, the investigation was performed only in hospitals, allowing the reclassification of cause of death in a more consistent way as a consequence of greater access to information and diagnostic exams. It is to be expected that in hospital services more information will be found clarifying causes of death by searching through medical records ${ }^{25,26}$.

In summary, the results presented here reinforce the importance of strategies to qualify the causes of death, which include both the training of physicians to adequately fill in the DC and in the investigation of these deaths. According to Ishitani et al. $^{15}$, it is necessary to invest in raising the awareness of health professionals about the importance of the DC as an instrument for producing health statistics to contribute to the development of actions and programs for prevention and treatment of diseases and problems that should receive intervention ${ }^{15}$.

Thus, aiming at prevention, it becomes extremely important to recommend that, in addition to the diagnosis of UnST, physicians try to reach a distinction between the diagnosis of hemorrhagic or ischemic stroke. Considering the prevention of new cases, it is important that information about the type of stroke is presented in the DC, since ischemic stroke has a cause most often related to atherosclerosis, while hemorrhagic stroke has a close relation with systemic arterial hypertension and rupture of cerebral aneurysms. Several options of prevention and primary care policies are now available to act on the main risks ${ }^{14}$. 


\section{CONCLUSION}

It was observed that deaths from UnST after investigation were reclassified with higher percentage to ischemic stroke, followed by hemorrhagic stroke. In addition, ischemic stroke was reclassified more frequently in more advanced age groups (70 years and over), while hemorrhagic stroke was reclassified more frequently in the age group of 30 to 69 years.

Moreover, a considerable amount of UnST was reclassified to other specific causes that are different from the stroke group, which shows difficulties related to the quality found both in the completion of DC and in the process of coding and selecting the underlying cause of death, or in the investigation of deaths, as well as in the availability of technologies for better medical diagnosis. Therefore, health service management needs to implement training of physicians to raise awareness on the importance of adequate DC completion. Reducing causes of death from GCs may contribute to improving estimates of mortality from ischemic and hemorrhagic stroke, in order to plan and implement health actions and assistance aimed at preventing atherosclerosis and controlling arterial hypertension, capable of reducing the incidence of these impairing events that are so costly for public health.

\section{REFERENCES}

1. André C. Manual de AVC. $2^{\text {a }}$ ed. Rio de Janeiro: Revinter; 2006.

2. Organização Mundial da Saúde. O Manual STEPS de Acidentes Vascular Cerebrais da OMS: enfoque passo a passo para a vigilância de acidentes vascular cerebrais/doenças não-transmissíveis e saúde mental, Organização Mundial da Saúde. Genebra; 2005.

3. Chaves MLF. Acidente vascular encefálico: conceituação e fatores de risco. Rev Bras Hipertens. 2000;7(4):372-82.

4. Radanovic M. Características do atendimento de pacientes com acidente vascular cerebral em hospital secundário. Arq Neuropsiquiatr. 2000;58(1):99-106. http:/ / dx.doi.org/10.1590/S0004-282X2000000100015

5. Mensah GA, Norrving B, Feigin VL. Global burden of stroke. Neuroepidemiology. 2015;45(3):143-5. https: / / doi.org/10.1161/CIRCRESAHA.116.308413

6. Feigin VL, Krishnamurthi RV, Parmar P, Norrving B, Mensah GA, Bennett DA, et al. Update on the global burden of ischaemic and haemorrhagic stroke (1990-2013): the GBD 2013 Study. Neuroepidemiology. 2015;45(3):161-76. https: / / dx.doi.org/10.1159\%2F000441085

7. Amarenco P, Bogousslavsky J, Caplan LR, Donnan GA, Hennerici MG. Classification of stroke subtypes. Cerebrovasc Dis. 2009;27(5):493-501. https: / / doi.org/ $10.1159 / 000210432$
8. Mortel KF, Meyer JS, Sims PA, McClintic K. Diabetes mellitus as a risk factor for stroke. South Med J. 1990;83(8):904-11. https:/ / doi.org/ 10.1097/00007611-199008000-00014

9. Aring CD, Merritt HH. Differential diagnosis between cerebral hemorrhage and cerebral thrombosis. Arch Intern Med. 1935;56(3):435-54. https:/ / doi.org/ 10.1001 / archinte.1935.00170010023002

10. Sacco RL, Wolf PA, Gorelick PB. Risk factors and their management for stroke prevention: outlook for 1999 and beyond. Neurology. 1999;53(7 Suppl 4):S15-24.

11. Kannel WB. Framingham study insights into hypertensive risk of cardiovascular disease. Hypertens Res. 1995;18(3):181-96. https:/ / doi.org/10.1291/ hypres. 18.181

12. Murray CJ, Lopez AD. Mortality by cause for eight regions of the world: global burden of disease study. Lancet. 1997;349(9061):1269-76. https: / / doi.org/ 10.1016/S0140-6736(96)07493-4

13. Brasil. Ministério da Saúde. Informações de saúde (Tabnet): estatísticas vitais: mortalidade geral [Internet]. Brasília, DF; 2008 [updated 2016Jan 25; cited 2019 Aug 27]. Available from: http://www2.datasus. gov.br $/$ DATASUS $/$ index.php?area $=0205 \&$ id $=6937$

14. GBD 2015 Mortality and Causes of Death Collaborators. Global, regional, and national life expectancy, allcause mortality, and cause-specific mortality for 249 
causes of death, 1980-2015: a systematic analysis for the Global Burden of Disease Study 2015. Lancet. 2016;388(10053):1459-544. https://doi.org/10.1016/ S0140-6736(16)31012-1

15. Ishitani LH, Teixeira RA, Abreu DMX, Paixão LMMM, França EB. Qualidade da informação das estatísticas de mortalidade: códigos garbage declarados como causas de morte em Belo Horizonte, 2011-2013. Rev Bras Epidemiol. 2017;20(Suppl 1):34-45. http:/ / dx.doi.org/10.1590/1980-5497201700050004

16. Murray CJL, Lopez AD. Estimating causes of death: new methods and global and regional applications for 1990. In: Murray CJL; Lopez AD, editores. The global burden of disease. Boston: Harvard School of Public Health; 1996. p. 118-200.

17. Naghavi M, Makela S, Foreman K, O’Brien J, Pourmalek F, Lozano R. Algorithms for enhancing public health utility of national causes-of-death data. Popul Health Metrics. 2010;8:9. https:/ / doi.org/ 10.1186/1478-7954-8-9

18. Truelsen T, Krarup LH, Iversen HK, Mensah GA, Feigin VL, Sposato LA, et al. Causes of death data in the Global Burden of Disease estimates for ischemic and hemorrhagic stroke. Neuroepidemiology. 2015;45(3):152-60. https:/ / doi.org/10.1159/000441084

19. Organização Mundial de Saúde. Classificação Estatística Internacional de Doenças e Problemas Relacionados à Saúde: CID-10. $8^{\text {a }}$ ed. São Paulo: Editora da Universidade de São Paulo; 2012.

20. Abreu DMX, Drumond EF, França EB, Ishitani LH, Malta DC, Machado CJ. Análise comparativa de classificações de causas evitáveis de morte em capitais brasileiras: o caso das doenças cerebrovasculares. Rev Bras Estud Popul. 2010;27(2):447-55. http:/ / dx.doi.org/ 10.1590/S0102-30982010000200014

21. Brasil. Ministério da Saúde, Melhoria do Diagnóstico de Casa de Morte no Brasil. Protocolo de investigação de óbitos com causas classificadas como códigos "garbage": sessenta cidades do Brasil. Brasília, DF; 2017 [cited 2019 Sep 3]. Disponível em: http://www1.saude.ba.gov.br/dis/arquivos_pdf/ Protocolo-Investigacao-Codigos-Garbage-60-CidAbril-2017.pdf

22. Serina P, Riley I, Stewart A, Flaxman AD, Lozano R, Mooney MD, etal. A shortened verbal autopsy instrument for use in routine mortality surveillance systems. BMC Med. 2015;13:302. https://doi.org/10.1186/ s12916-015-0528-8

23. GBD 2015 Risk Factors Collaborators. Global, regional, and national comparative risk assessment of 79 behavioural, environmental and occupational, and metabolic risks or clusters of risks, 1990-2015: a systematic analysis for the Global Burden of Disease Study 2015. Lancet. 2016;388(10053):1659-724. https: / doi.org/10.1016/S0140-6736(16)31679-8

24. Cabral NL, Freire AT, Conforto AB, Santos N, Reis FI, Nagel V, et al. Increase of stroke incidence in young adults in a middle-income country: a 10-year population-based study. Stroke. 2017;48(11):2925-30. https: / / doi.org/10.1161/STROKEAHA.117.018531

25. Campos D, França E, Loschi RH, Souza MFM. Uso da autópsia verbal na investigação de óbitos com causa mal definida em Minas Gerais, Brasil. Cad Saúde Pública. 2010;26(6):1221-33. http:/ / dx.doi.org/ 10.1590/S0102-311X2010000600015

26. França EB, Teixeira RA, Ishitani LH, Duncan BB, Cortez-Escalante JJ, Morais Neto OL, et al. Causas mal definidas de óbito no Brasil: método de redistribuição baseado na investigação do óbito. Rev Saúde Pública. 2014;48(4):671-81. http:/ / dx.doi.org/10.1590/ S0034-8910.2014048005146

27. Silva FG, Tavares-Neto J. Avaliação dos prontuários médicos de hospitais de ensino do Brasil. Rev Bras Educ Med. 2007;31(2):113-26. http://dx.doi.org/ 10.1590/S0100-55022007000200002

28. Alves MA, Szpilman ARM, Poton WL. Avaliação do registro médico nos prontuários de um ambulatório de ensino, Vila Velha, ES. Rev Bras Pesqui Saúde, Vitória. 2015;17(3):69-77. https:/ / doi.org/10.21722/ rbps.v17i3.14138

Received: 06/12/2019

Final version presented on: 08/27/2019

Approved: 08/28/2019

Acknowledgements: The authors of this manuscript thank all health professionals who made feasible and carried out investigations in hospitals and other health services of the 60 cities participating in the project "Melhoria do Diagnóstico de Causa de Morte no Brasil”. (Improvement in the Diagnosis of Cause of Death in Brazil).

\footnotetext{
Authors' contribution: Mamed SN, Ramos AMO, Ishitani $\mathrm{LH}$, and França EB conceived, analyzed and interpreted the data, drafted the article and made a critical review of the work. Araújo VEM analyzed and interpreted the data, drafted the article and made a critical review of the manuscript. Jesus WS analyzed and interpreted the data and drafted the article. All authors approved the final version of the manuscript.
} 